\title{
Conhecimentos de Estudantes de Psicologia sobre Normas de Atuação com Indivíduos LGBTs ${ }^{1}$
}

\author{
Táhcita Medrado Mizael ${ }^{1}$ \\ Ariane Rico Gomes ${ }^{1}$ \\ ${ }^{1}$ Universidade Federal de São Carlos, SP, Brasil. \\ ${ }^{1}$ Universidade Federal de São Carlos, SP, Brasil. \\ Paula Pizzirani Marola ${ }^{2}$ \\ ${ }^{2}$ Universidade Estadual Paulista, SP, Brasil.
}

Resumo: Discussões sobre gênero e sexualidade têm sido abordadas em vários contextos. Na Psicologia, autarquias como o Conselho Federal de Psicologia (CFP) elaboraram diversos documentos orientando a prática psicológica com indivíduos LGBTs. Entretanto, pesquisas têm mostrado que esses saberes têm sido omitidos nos currículos de graduação em Psicologia de várias faculdades, o que pode acarretar concepções diversas àquelas normatizadas e, muitas vezes, patologizantes sobre indivíduos LGBTs, podendo levar a condutas preconceituosas e até opostas às recomendações do CFP. Assim, o objetivo dessa pesquisa foi analisar as concepções de alunos de graduação em Psicologia interessados nas temáticas de gênero e sexualidade, com relação à diversidade sexual e de gênero, assim como seus conhecimentos sobre as declarações do CFP a respeito das homossexualidades e identidades trans. Oitenta e dois alunos, de diferentes faculdades e períodos responderam um questionário com perguntas sobre a formação e dados sociodemográficos, conhecimentos acerca da diversidade sexual e de gênero, e sobre as concepções e recomendações do CFP com relação aosindivíduos LGBTs. Os resultados mostraram que, para a maioria dos participantes, suas concepções acerca das homossexualidades foram, em geral, condizentes com as concepções das autarquias responsáveis pela normatização e fiscalização do exercício profissional do psicólogo. Entretanto, quando se trata das identidades trans, há um desconhecimento e concepções diversas às normatizadas a respeito das definições correntemente utilizadas, além da patologização de tais identidades. Desse modo, mostra-se imprescindível o oferecimento de disciplinas sobre gênero e sexualidade na Psicologia.

Palavras-chave: Formação de Psicólogos, Psicologia, Diversidade Sexual e de Gênero, LGBT, Currículo.

\footnotetext{
${ }^{1}$ Táhcita M. Mizael é bolsista da Fundação de Amparo à Pesquisa do Estado de São Paulo (FAPESP - Processo $n^{\circ}$ 15/10225-5). A autora é afiliada ao Instituto Nacional de Ciência e Tecnologia sobre Comportamento, Cognição e Ensino (INCT-ECCE), apoiado pelo Conselho Nacional de Desenvolvimento Científico e Tecnológico (CNPq Processos no 573972/2008-7 e 465686/2014-1) e pela Fundação de Amparo à Pesquisa do Estado de São Paulo (FAPESP - Processos no 2008/57705-8 e 2014/50909-8). A autora agradece às professoras Carla Mattos e Marina Nucci pelo apoio durante a especialização em gênero e sexualidade e aos colegas de turma pelas discussões dentro e fora da sala de aula.
} 


\title{
Psychology Students' Knowledge Concerning Guidelines for Psychological Practice with LGBTs
}

\begin{abstract}
Debates regarding the topics of gender and sexuality are present in a myriad of contexts. In the field of Psychology, autarchies such as the Federal Council of Psychology (CFP, in Portuguese) produced documents and guidelines for psychological practice with LGBTs. Still, research has pointed out that these guidelines have been omitted in the curriculum of Psychology as a major, which could lead to conceptions that differed from the regulated by those autarchies, including prejudicial attitudes, and discrimination or practices opposed to the recommendations. In this sense, the present study aimed to analyze Psychology students' conceptions regarding gender and sexual diversity, as well as the students' knowledge concerning the official guidelines for psychological practice with LGBTs. Eighty-two Brazilian Psychology students, from different universities and periods, answered a questionnaire about their academic education, demographic data, and knowledge regarding gender and sexual diversity, as well as about the official guidelines for professional practice with LGBTs. Results showed that, for most participants, their conceptions about the homosexualities were generally consistent with the conceptions of the autarchies responsible for normalizing and supervising psychologist's professional practice. However, students showed conceptions that differed from the regulated ones regarding the definitions of trans identities, including pathologizating them, which calls for the inclusion of the subjects of gender and sexuality in the Psychology curriculum.
\end{abstract}

Keywords: Academic Education, Psychology, Sexual and Gender Diversity, LGBT, Curriculum.

\section{Conocimientos de Estudiantes de Psicología sobre las Normas de Actuación con Individuos LGBTs}

Resumen: Las discusiones sobre género y sexualidad se han abordado en varios contextos. En la psicología, autoridades como el Consejo Federal de Psicología (CFP) han producido varios documentos que guían la práctica psicológica con individuos LGBTs. Sin embargo, la investigación ha demostrado que este conocimiento se ha omitido en los planes de estudios de estudiantes de Psicología de pregrado de varias universidades, lo que puede conducir a concepciones diferentes a las estandarizadas y a menudo patologizadoras sobre personas LGBTs, y puede conducir a prejuicios e incluso oponerse a las recomendaciones del CFP. Por lo tanto, el objetivo de esta investigación fue analizar las concepciones de los estudiantes universitarios de psicología interesados en los temas de géneroysexualidad, en relación conla diversidad sexual yde género, asícomo sus conocimientos sobre las declaraciones del CFP sobre homosexualidades e identidades trans. Ochenta y dos estudiantes de diferentes universidades y períodos respondieron un cuestionario con preguntas sobre su formación académica y datos sociodemográficos, conocimiento sobre la diversidad sexual y de género, y las concepciones yrecomendaciones delCFPcon respecto alas personasLGBTs.Los resultadosmostraron que, para la mayoría de los participantes, sus concepciones sobre las homosexualidades eran, en general, consistentes con las concepciones de las autoridades responsables por la estandarización y supervisión de la práctica profesional del psicólogo. Sin embargo, cuando se trata de identidades trans, existe una falta de conocimiento y concepciones diferentes de las estandarizadas con respecto a las definiciones utilizadas actualmente, además de la patologización de tales identidades. Por lo tanto, es esencial ofrecer disciplinas sobre género y sexualidad en los cursos de Psicología.

Palabras clave: Formación de Psicólogos, Psicología, Diversidad Sexual y de Género, LGBTs, Plan de estudios. 
Discussões em torno da temática de gênero $e$ sexualidade têm estado presentes nos últimos anos, sendo possível verificar tais discussões não só em âmbitos abertamente políticos - como a discussão sobre a presença do termo gênero nos Planos Municipais de Educação de vários Estados brasileiros (ver, por exemplo, Britto \& Reis, 2015), e nos projetos de lei (PL) que são propostos e votados na Câmara (como o PL $n^{\circ}$ 122/2006, que criminaliza a homofobia) -, mas nos mais diversos âmbitos (escolas, empresas, universidades, instituições de saúde, e espaços públicos em geral). Essa visibilidade dos indivíduos com sexualidades e/ou performances de gênero não hegemônicas tem auxiliado, entre outras coisas, na desmistificação de supostas características inerentes a essas pessoas (como uma maior promiscuidade nos homens gays), assim como no fortalecimento da luta por direitos que, no papel (vide a Constituição de 1988), deveriam ser de todos.

A Psicologia, como uma profissão cujo objetivo é promover "o respeito à dignidade e integridade do ser humano" (Brasil, 1992, p. 1), deve acompanhar as discussões em torno desse tema e se posicionar sobre o assunto, uma vez que os profissionais dessa área atuam em vários campos e seus saberes têm implicações diretas na saúde mental dos indivíduos com os quais se trabalha. Historicamente, a Psicologia contribuiu na legitimação do preconceito aos LGBTs (lésbicas, gays, bissexuais, travestis e transexuais) durante muito tempo, ao considerar as homossexualidades e as identidades trans como patologias e/ou anormalidades (Baptista, 1999; Borges, 2009; Borges, Canuto, Oliveira, \& Vaz, 2013; Dinis, 2011; Guimarães, 2009; Oliveira, 2010). Entretanto, nas últimas décadas, pode-se dizer que a Psicologia tem realizado esforços para "reverter" esse histórico discriminatório (por exemplo, Nogueira, 2001; Nuernberg, 2005), de modo a se posicionar contrariamente às concepções patologizantes de gênero e sexualidades dissidentes ${ }^{1}$.

Os dois documentos brasileiros principais em que o Conselho Federal de Psicologia (CFP) se posiciona a respeito da diversidade sexual e de gênero são a Resolução $n^{\circ} 01$ (1999), que estabelece as normas de atuação das psicólogas e psicólogos a respeito da orientação sexual, e uma nota técnica emitida em 2013 (Conselho Federal de Psicologia [CFP], 2013) sobre o processo transexualizador e outras formas de assistência às pessoas trans. A Resolução $\mathrm{n}^{\circ} 01$ (1999) deixa claro que a homossexualidade "não constitui doença, nem distúrbio, nem perversão”, e que é dever das psicólogas e psicólogos "contribuir com o seu conhecimento para o esclarecimento sobre as questões da sexualidade, permitindo a superação de preconceitos e discriminações" (p. 1). Além disso, tal Resolução: a) proíbe às psicólogas e psicólogos exercer quaisquer condutas que levem à patologização de comportamentos ou práticas homoeróticas, assim como adotar práticas coercitivas com o intuito de iniciar quaisquer tipos de tratamentos não solicitados; b) estabelece que as psicólogas e os psicólogos não podem contribuir com eventos e/ou serviços cujo intuito seja um suposto tratamento e/ou cura das homossexualidades; e c) veda o pronunciamento de psicólogas e psicólogos, no âmbito público ou privado, de qualquer discurso que reforce os preconceitos sociais existentes com a relação à homossexualidade como uma desordem psíquica (Conselho Regional de Psicologia de São Paulo [CRP-SP], 1999). Na nota sobre o processo transexualizador, o CFP também declara que "a transexualidade e a travestilidade não constituem condição psicopatológica, ainda que não reproduzam a concepção normativa de que deve haver uma coerência entre sexo biológico/gênero/ desejo sexual" (CFP, 2013, p. 2).

Além desses dois documentos, com certa frequência colunas sobre o assunto são publicadas nos sites dos Conselhos Regionais de Psicologia (CRP), visibilizando questões como sua posição contrária ao Projeto de Decreto Legislativo (PDL) 234/2011, conhecido como "cura gay", cujo objetivo é revogar parte da Resolução $\mathrm{n}^{\circ} 01$ (1999) do CFP (CRP-SP, 2013), e a defesa de uma Psicologia laica em detrimento da religião das psicólogas e dos psicólogos (Aguiar, 2003). Também já foram publicadas colunas com a constatação de que as resoluções do CFP são pouco abordadas durante os anos de formação profissional (CRP-SP, 2005), e reiterando que as homossexualidades, assim como as identidades trans não constituem doença (CRP-SP, 1999, 2007, 2008).

\footnotetext{
${ }^{1}$ Rubin (1984) utiliza o termo sexualidades dissidentes para se referir às sexualidades que estão à margem, como as sexualidades não reprodutivas (homossexuais ou não), sexo em lugares públicos, práticas eróticas sadomasoquistas, etc. No presente texto, o termo "gênero e sexualidades dissidentes" é utilizado para se referir às orientações sexuais homossexual (lésbica e gay) e bissexual, e às identidades de gênero trans (ou seja, àquelas que não se conformam a suposta coerência entre o sexo assignado no nascimento e a identidade de gênero de um indivíduo).
} 
Apesar da existência desses documentos, emitidos pelas autarquias responsáveis pela normatização e orientação do exercício profissional, como o CFP e os CRPs, diversas pesquisas mostram que tanto alunos quanto profissionais de Psicologia têm tido, com certa frequência, atitudes preconceituosas e patologizantes com relação a indivíduos LGBTs (Araujo, Oliveira, Souza, \& Castanha, 2007; Dinis, 2011; Lima \& Uziel, 2013; Santos, Costa, Carpenedo, \& Nardi, 2011; Silva, 2014; Souza, Silva, \& Santos, 2017; Vieira, Hernández, \& Uziel, 2013). Existe também a hipótese, levantada a partir dos dados coletados de um estudo (Dinis, 2012), de que os estudantes de Psicologia não conhecem as orientações dadas pelas autarquias supracitadas com relação às identidades de gênero e sexualidades não hegemônicas.

Stern (2006), por exemplo, realizou uma pesquisa com 242 alunos de vários cursos da área da saúde, incluindo Psicologia, com o intuito de verificar suas atitudes com relação ao atendimento de homossexuais, assim como descobrir se os participantes já leram algo sobre o assunto. Os resultados mostraram que a minoria dos alunos tinha lido algo sobre o tema, o que se refletiu nas respostas dadas pelos participantes: dentre os alunos de Psicologia, mais de $20 \%$ relataram que homossexuais tinham maiores chances de contrair aids, e $32 \%$ afirmaram ser possível reverter um adulto homossexual em heterossexual. Outro dado assustador foi a presença de professores com condutas homofóbicas ${ }^{2}$ na Psicologia: $16 \%$ dos alunos afirmaram ter presenciado posturas homofóbicas de seus professores.

Silva (2014) também encontrou atitudes negativas com relação à diversidade sexual e de gênero. Trinta alunos de Psicologia responderam um questionário que contemplava questões sobre gênero e orientação sexual, e os resultados mostraram estranhamento, além de desconhecimento, no que se refere às identidades trans. A concepção de que a mudança de sexo estaria necessariamente ligada ao exercício da sexualidade também foi presente na resposta de alguns alunos (afirmar, por exemplo, que um indivíduo cujo sexo assignado no nascimento foi masculino deseja "mudar" de sexo com o objetivo de exercer seu desejo por homens). Entretanto, apesar de as respostas refletirem falta de conhecimento sobre a temática, todos os participantes concordaram que a discussão destes temas é fundamental para sua formação, argumentando, por exemplo, que se fossem aptos para lidar com essas demandas, não precisariam encaminhar tais casos.

A pesquisa de Dinis (2012), por outro lado, encontrou resultados diferentes, apontando atitudes mais positivas com relação à diversidade sexual e de gênero. Dos 103 participantes, alunos do $4^{\circ}$ ano do curso de Psicologia, $89 \%$ declararam não ter problemas em contratar uma pessoa homossexual; a mesma proporção de alunos alegou não ter objeções caso tivesse um filho ou filha homossexual; $91 \%$ declararam que não mudariam suas condutas com um colega, caso descobrissem que ele ou ela era homossexual, e $70 \%$ afirmaram não ter preconceitos com relação à diversidade sexual. Entretanto, ao analisar as justificativas dadas pelos participantes, se torna saliente a questão do socialmente aceito. Alguns participantes comentaram, por exemplo, que não modificariam suas condutas caso descobrissem que um colega fosse homossexual a não ser que tal indivíduo seja seu melhor amigo; outros disseram que, apesar de participar sem problemas do mesmo ambiente que uma pessoa homossexual, teriam medo de acreditarem que eles próprios também fossem homossexuais. Esses exemplos ilustram o que alguns pesquisadores têm chamado de preconceito sutil (ver, por exemplo, Lacerda, Pereira, \& Camino, 2002). Desse modo, as justificativas evidenciam que as respostas, aparentemente positivas, são, na verdade, discursos politicamente corretos.

Ainda nessa pesquisa, outro dado merece destaque: foi perguntado aos participantes se eles ajudariam um cliente a mudar sua orientação sexual. Trinta e oito por cento declarou que ajudariam, 35\% não ajudariam, e $27 \%$ não responderam a questão (essa foi também a pergunta com o maior número de omissões no item "justifique sua resposta"). A hipótese do autor para tal resultado é um reflexo do desconhecimento da Resolução no 01 (1999), que proíbe explicitamente aos psicólogos e psicólogas um suposto tratamento ou cura das homossexualidades. Além disso, mesmo entre os participantes que se posicionaram de forma contrária em auxiliar na mudança da orientação sexual de um cliente, nenhum deles citou a resolução do CFP como justificativa para suas respostas, 0 que fortalece a hipótese de desconhecimento sobre as

${ }^{2}$ Homofobia (ou LGBTfobia) é o nome dado ao preconceito por orientação e/ou prática sexual homossexual ou bissexual e/ou pela identidade de gênero trans (não coerência entre o sexo assignado no nascimento e a identidade de gênero do indivíduo). 
normas emitidas pelas autarquias responsáveis pela normalização e fiscalização do exercício do profissional da Psicologia para lidar com situações envolvendo as homossexualidades.

Uma pergunta que surge nesse contexto diz respeito à influência do interesse nessa temática com o posicionamento de um indivíduo com relação à diversidade sexual e de gênero: será que o fato de um estudante de Psicologia ter interesse nas temáticas de gênero e sexualidade é suficiente para que ele busque maneiras de manter-se informado sobre a literatura da área, assim como sobre os posicionamentos emitidos pelas autarquias responsáveis pela normatização do exercício do profissional da Psicologia? Existe realmente a necessidade de se criarem disciplinas, cursos de extensão e/ou outras atividades que proporcionem aos estudantes a oportunidade de aprender sobre essas temáticas?

A presente pesquisa se baseia nesses questionamentos, muito utilizados por pessoas contrárias ao ensino das temáticas de gênero e sexualidade nos cursos de graduação em Psicologia (mas não restrito a) e na hipótese de Dinis (2012) de que os estudantes de Psicologia desconhecem as normatizações emitidas pelas autarquias supracitadas, ampliando a literatura da área ao avaliar não só os conhecimentos dos estudantes de Psicologia com relação às temáticas de gênero e sexualidade de maneira geral, mas especificamente o conhecimento do conteúdo da Resolução $\mathrm{n}^{\circ} 001$ (1999), assim como da nota técnica emitida em 2013 sobre a atuação das psicólogas e psicólogos nas identidades trans, algo inédito em uma pesquisa desse tipo. Além disso, essa pesquisa buscou verificar se a presença de disciplinas de gênero e sexualidade no currículo se correlaciona com um maior conhecimento das normativas acima referidas.

Portanto, os objetivos principais da presente pesquisa foram: a) verificar se estudantes de Psicologia conhecem as orientações das autarquias responsáveis pela normatização e orientação do exercício profissional, a respeito da atuação com indivíduos com orientação sexual homossexual, bissexual ou práticas homoeróticas, assim como dos indivíduos com identidades trans; e b) analisar quais são as concepções destes estudantes acerca das identidades de gênero e práticas ou orientações sexuais não hegemônicas. Como objetivos secundários: a) examinar se os participantes tiveram disciplinas sobre gênero e sexualidade durante a graduação, assim como leituras por conta própria acerca dessas temáticas; e b) buscar possíveis relações entre a existência de disciplinas e/ ou de leituras realizadas por conta própria que abordem a temática "gênero e sexualidade", com concepções não patologizantes da sexualidade e do gênero.

\section{Método}

\section{Participantes}

Participaram 82 alunos de cursos de Psicologia de diferentes faculdades do Brasil, com idades entre $18 \mathrm{e}$ 27 anos. Sessenta participantes declararam ser do sexo feminino $(73,2 \%)$ e 22 , do sexo masculino $(26,8 \%)$. Os alunos estavam entre o primeiro e o último ano do curso, sendo a maioria do segundo e terceiro anos. A distribuição dos alunos nas diferentes regiões foi a seguinte: região Sudeste $=67,2 \%$, região Sul $=14,7 \%$, região Centro-oeste $=2,6 \%$, região Nordeste $=2,6 \%$. Nenhum participante declarou ser da região Norte, e $12,9 \%$ não forneceram este dado. Todos os participantes firmaram o Termo de Consentimento Livre e Esclarecido (TCLE), e a pesquisa foi aprovada pelo comitê de Ética da Universidade Federal de São Carlos (parecer $\mathrm{n}^{\circ}$ 1.680.630).

\section{Materiais e Procedimento}

Foi utilizado um questionário eletrônico (Apêndice), formulado de modo a contemplar quatro pontos:

a) Dados sociodemográficos: idade, sexo assignado no nascimento, identidade de gênero, orientação sexual, pertencimento a uma religião, ou ausência desta;

b) Formação: ano do curso, existência de disciplinas que abordem gênero e/ou sexualidade, leituras fora do currículo acerca do tema e por quais motivos. Também foi perguntado se os alunos presenciaram comentários homofóbicos de seus professores ou professoras da graduação;

c) Concepções acerca dos temas gênero e sexualidade: como veem a heterossexualidade, a homossexualidade e as práticas heterossexuais e homossexuais, definições de orientação sexual, identidade de gênero, homossexualidade, bissexualidade, heterossexualidade, transexualidade e travestilidade; possíveis explicações para a heterossexualidade, homossexualidades e identidades trans; e 
d) Conhecimento das orientações das autarquias responsáveis pela normatização e orientação do exercício profissional a respeito da diversidade sexual e de gênero: se os alunos conhecem, especificamente, os conteúdos da Resolução $\mathrm{n}^{\circ} 01$ (1999) e da nota sobre o processo transexualizador e identidades trans, publicada em 2013.

O questionário foi formulado a partir da leitura de estudos prévios que trabalharam a mesma temática, de modo a conter questões abertas e fechadas, o que caracteriza a pesquisa quali-quantitativa. O convite para a pesquisa foi feito em grupos de e-mail de faculdades, além de ser divulgado em diferentes grupos de Psicologia do Facebook, e também de grupos que discutem gênero e sexualidade. A autora principal se apresentava, e convidava alunos de graduação em Psicologia para participarem. Como o questionário não foi dado de maneira "compulsória" para algumas turmas de alunos, como ocorreu nas pesquisas anteriores, hipotetizou-se que somente alunos interessados na temática responderiam o questionário. Isso pode ser confirmado em uma das perguntas sobre o interesse dos alunos em estudar a temática em um curso.

\section{Forma de análise dos resultados}

Utilizou-se a análise de conteúdo para aprofundamento dos resultados obtidos nos questionários. Esse método, muito utilizado em pesquisas qualitativas, pode ser definido como "um conjunto de técnicas de análise das comunicações que visam obter, por procedimentos, sistemáticos e objetivos de descrição do conteúdo das mensagens, indicadores (quantitativos ou não) que permitam a inferência de conhecimentos relativos às condições de produção/recepção destas mensagens" (Bardin, 1979, p. 42).

Desse modo, a análise de conteúdo permite ultrapassar incertezas e enriquecer a leitura, tendo por base um modelo formal (Bardin, 1979). A escolha desse tipo de análise se justifica na medida em que a análise de conteúdo permite avaliar, em última instância, qualquer forma de comunicação, utilizando-se da inferência e da interpretação como técnicas do processo de análise e com ênfase na contextualização da mensagem (ou seja, suas condições de produção) para ir além desta. A "unidade de codificação básica” para uma análise corresponderia à frase, limitada por dois sinais de pontuação, considerada como mensagem mínima, como sinônimo de um signo ou um símbolo suscetível de ter mais de um significado (Bardin, 1979), o que amplia o escopo para discussão.

\section{Resultados}

Após a tabulação dos dados, as respostas foram divididas em categorias, abarcando os quatro pontos supracitados (dados sociodemográficos, relativos à formação dos participantes, aos conhecimentos de gênero e sexualidade, e às orientações do CFP a respeito de indivíduos LGBTs). Respostas que apontaram funções semelhantes (como explicações biológicas para a homossexualidade - Lacerda et al., 2002) foram agrupadas, de modo a facilitar a análise. A frequência de respostas em cada categoria foi avaliada, buscando relações com outras variáveis (religiosidade, por exemplo).

\section{Caracterização dos participantes}

Além das informações previamente citadas, 51 participantes declararam ser heterossexuais $(62,2 \%)$, 18 bissexuais (22,0\%), sete homossexuais (8,5\%), e seis "outra classificação" (7,3\%). Cinquenta e oito declararam possuir identidade de gênero feminina $(70,7 \%)$ e 18 masculina $(22,0 \%)$. Cinco se declararam como gênero não binário $(6,1 \%)$ e um como "outra classificação" (1,2\%). Com relação à religião, a maioria dos participantes se declarou como ateus $(19 ; 23,2 \%)$ ou agnósticos (11; 13,4\%). Dez participantes declararam ser católicos $(12,2 \%)$, oito protestantes $(9,8 \%)$, sete kardecistas $(8,5 \%)$, e cinco pertencentes à umbanda/ candomblé $(6,1 \%)$. Vinte e dois participantes responderam que pertenciam a uma classificação diferente $(26,8 \%)$ no quesito religião.

\section{Concepções acerca dos temas gênero e sexualidade}

Praticamente todos os participantes responderam todas as questões. Quando determinada questão teve um número menor de respostas, isso foi evidenciado. A primeira questão foi "o que você entende por orientação sexual". Apenas sete participantes responderam essa questão. Desses, seis responderam em consonância com as definições mais correntes na Psicologia, sociologia e áreas afins, relatando que a orientação sexual é o nome dado a inclinação afetivo-sexual de uma pessoa. Um desses participantes especificou três orientações sexuais (homossexualidade, 
heterossexualidade e bissexualidade); outro definiu apenas a homo e heterossexualidade, e um terceiro adicionou a essas duas a possibilidade de se relacionar com alguém sem um gênero definido. $\mathrm{O}$ sétimo participante respondeu que orientação sexual seria um rótulo dado pela sociedade.

Na pergunta "Bissexual significa...", a maioria dos participantes respondeu relacionamento com pessoas de ambos os sexos $(\mathrm{N}=39)$, seguido por pessoas de ambos os gêneros ( $\mathrm{N}=23)$, homens e mulheres (13), e mais de um gênero (respostas que não especificaram os gêneros masculino e feminino; $\mathrm{N}=5$ ). Duas respostas discrepantes das categorias foram "sexualidade humana" $(\mathrm{N}=1)$, e "atitude" $(\mathrm{N}=1)$. As categorias na pergunta "Heterossexual significa..." foram relacionamento afetivo-sexual com pessoas do sexo oposto $(\mathrm{N}=$ 47), do gênero oposto ( $\mathrm{N}=18)$, de gênero diferente do seu/"oposto" ( $\mathrm{N}=9$ ), sexo diferente do seu/"oposto" $(\mathrm{N}=3)$, do mesmo gênero $(\mathrm{N}=1)$, e outros $(\mathrm{N}=4)$. Em "Homossexual significa...", as categorias elencadas foram relacionamento afetivo-sexual com pessoas do mesmo sexo $(\mathrm{N}=49)$, do mesmo gênero $(\mathrm{N}=28)$, do mesmo sexo/gênero $(\mathrm{N}=1)$, e outros $(\mathrm{N}=4)$. Portanto, nessas três questões, a maioria dos participantes usa o termo sexo para falar de orientação sexual, seguido do termo gênero.

Em "O que é a homossexualidade para você?", os participantes selecionaram uma ou mais alternativas que considerassem corretas. Setenta e sete participantes responderam "uma orientação sexual" (93,9\%). Dez participantes responderam "uma escolha" $(12,2 \%)$ e outras 10 (12,2\%), "um estilo de vida". Com relação à heterossexualidade, o padrão de respostas se repete: 76 participantes responderam "uma orientação sexual" (92,7\%), 10 "uma escolha" (12,2\%) e outras $10(12,2 \%)$ "um estilo de vida".

Na pergunta "Você acha que a homossexualidade é algo que tem uma causa específica?", sessenta e sete participantes responderam que "não" (81,7\%), e 12 (14,6\%) responderam não saber ou não ter opinião formada sobre o assunto. Dois participantes responderam "abusos sexuais/ traumas sofridos na infância/ conflitos parentais", e um "falta de respeito/desvio de conduta/ falta de valores morais". As 65 respostas justificando "não acreditar em uma causa específica" foram elencadas em: explicações citando que a orientação sexual é algo multideterminado $(\mathrm{N}=16)$, que a pessoa nasce assim $(\mathrm{N}=9)$, que há uma influência genética, porém, sem constituir doença $(\mathrm{N}=2)$, e que é algo genético $(\mathrm{N}=1)$. A descoberta através de experiências também foi relatada $(\mathrm{N}=2)$, assim como um caráter inerente: "faz parte do que a pessoa é e não se muda" ( $\mathrm{N}=1)$. Com relação à multideterminação, os fatores mais citados foram sociais $(\mathrm{N}=10)$, biológicos $(\mathrm{N}=8)$ e genéticos $(\mathrm{N}=6)$. Na mesma pergunta com relação à heterossexualidade, sessenta e nove participantes responderam que não há causa específica $(84,1 \%)$, e $13(15,9 \%)$ responderam não saber ou não ter opinião formada sobre o assunto. As 62 justificativas dadas indicaram que a heterossexualidade é algo multideterminado $(\mathrm{N}=16)$, que a pessoa nasce assim $(\mathrm{N}=9)$, que é genético $(\mathrm{N}=1)$, ou descoberto através de experiências $(\mathrm{N}=1)$. Novamente, um participante disse que a heterossexualidade "faz parte do que a pessoa é e não se muda”. Com relação à determinação, exatamente as mesmas respostas foram citadas.

Quando perguntados sobre os sentimentos mais expressivos que os participantes têm em relação aos homossexuais, 78 participantes $(95,1 \%)$ responderam "respeito", em comparação com 64 respostas desse tipo com relação à heterossexualidade $(78,0 \%)$. Trinta e nove $(47,6 \%)$ responderam "admiração" (nove responderam isso na pergunta sobre heterossexualidade, o equivalente à $11,0 \%$ da amostra). Trinta e seis participantes responderam "orgulho" (43,9\%) versus cinco com relação à heterossexualidade $(6,1 \%)$. Vinte e sete participantes $(32,9 \%)$ responderam "ternura" em comparação com sete na pergunta sobre heterossexualidade $(8,5 \%)$. Doze participantes disseram sentir "indiferença" com relação aos homossexuais (14,6\%). Esse número subiu para 34 participantes quando perguntados sobre os sentimentos com relação aos heterossexuais $(41,5 \%)$. Seis participantes responderam sentir raiva com relação aos heterossexuais $(7,3 \%)$. Nenhum participante respondeu dessa forma com relação a indivíduos homossexuais.

Na questão "Qual situação deixaria você mais constrangido(a) com relação aos homossexuais?", 78 participantes $(95,1 \%)$ disseram não se sentir constrangidos em nenhuma das situações propostas. Em conjunto, oito participantes $(7,3 \%)$ disseram sentir-se constrangidos ao "ver dois homens se beijando", "ver duas mulheres se beijando", e/ou "ter uma filha lésbica".

Na pergunta "Você é a favor do casamento entre homossexuais?", 78 pessoas se mostraram favoráveis ao casamento $(95,1 \%)$, três se mostraram indiferentes $(3,7 \%)$, e uma desfavorável. Os números com relação ao casamento entre heterossexuais foram bastante 
semelhantes: 75 respostas favoráveis $(91,5 \%)$, seis indiferentes $(7,3 \%)$, e uma sem opinião formada sobre o assunto. Com relação às justificativas, a maioria dos participantes respondeu que o casamento, independentemente da orientação sexual, constitui um direito (58 pessoas na pergunta com relação aos homossexuais e 48 com relação aos heterossexuais). As outras justificativas foram relacionadas à celebração do amor (oito na pergunta sobre o casamento homoafetivo, e sete sobre o casamento heterossexual), "cada um faz o que quer" (sete no casamento homo, e 14 no heterossexual), e ao respeito, independentemente de suas opiniões pessoais (cinco para a questão sobre casamento homo, e quatro para o heterossexual).

Com relação à adoção por casais homo e heterossexuais, a maioria dos participantes se mostraram favoráveis (79 participantes $=96,3 \%$ e 78 participantes $=95,1 \%$, respectivamente). Os demais relataram não ter opinião formada (três participantes na questão sobre adoção por homossexuais, e quatro na pergunta sobre adoção por heterossexuais). As justificativas da maioria foram, novamente, a questão dos direitos (17 respostas na pergunta sobre adoção homo e 14 sobre adoção heterossexual), e principalmente à orientação sexual não ser impeditivo para adoção (58 respostas na questão sobre adoção homo e 63 sobre a adoção heterossexual), adicionando que o mais importante são condições psicológicas e financeiras, no sentido de dar carinho e afeto, além de suprir as necessidades básicas da(do) adotanda(o) em questão.

Até o momento, as perguntas abordaram questões mais relativas à sexualidade e a maioria dos participantes, de forma geral, demonstraram concepções e posicionamentos que estão de acordo com as definições atuais das autarquias responsáveis pela normatização e orientação do exercício profissional. A seguir, as perguntas se referem prioritariamente às questões de gênero.

Na pergunta "O que você entende por transexualidade?", as respostas foram categorizadas em: identificação com gênero diferente do assignado ao nascer $(\mathrm{N}=19)$, identificação com gênero oposto ao assignado ao nascer $(\mathrm{N}=4)$, identificação com gênero diferente do sexo biológico ( $\mathrm{N}=12)$, identificação com gênero oposto ao sexo biológico $(\mathrm{N}=6)$, identificação com sexo oposto ao que nasceu ( $\mathrm{N}=18)$, não se sentir bem no corpo em que nasceu ( $\mathrm{N}=7)$, identificar-se com sexo/gênero diferente do atribuído $(\mathrm{N}=4)$, mudança de sexo $(\mathrm{N}=4)$.
A questão "O que você entende por travestilidade?" gerou as categorias: conduta condizente com gênero diferente do sexo biológico $(\mathrm{N}=13)$, identificação com gênero oposto ao sexo biológico $(\mathrm{N}=7)$, identificação com gênero oposto ao sexo biológico, porém sem mudança do sexo $(\mathrm{N}=6)$, conduta condizente com sexo diferente do biológico $(\mathrm{N}=6)$, usar roupas do sexo oposto $(\mathrm{N}=13)$, usar roupas do gênero oposto $(\mathrm{N}=3)$, identidade de gênero $(\mathrm{N}=5)$, identificação com ambos os gêneros $(N=2)$, sinônimo de transexualidade $(\mathrm{N}=6)$, e "não sei a diferença entre os dois" $(\mathrm{N}=4)$.

Em "Você acha que a transexualidade é algo que tem uma causa específica?", 46 participantes responderam que não $(56,1 \%)$. Vinte e seis relataram não possuir opinião formada sobre o assunto $(31,7 \%)$, dois responderam que ela estaria relacionada a problemas hereditários, má formação gestacional ou disfunções hormonais. Os demais atribuíram a transexualidade a outras causas (oito participantes $=9,8 \%$ ). Apenas 39 participantes justificaram suas respostas, 10 apontando para a multideterminação causal, e nove para uma “característica do sujeito”. Quatro reiteraram que é uma identidade de gênero, e dois apontaram que os indivíduos nascem assim.

Na mesma pergunta com relação à travestilidade, 44 participantes responderam que não havia uma causa específica (53,7\%). Trinta e dois relataram não possuir opinião formada sobre o assunto $(31,7 \%)$, um número maior em comparação com a mesma pergunta sobre transexualidade. Os seis participantes restantes atribuíram a travestilidade a outras causas (7,3\%). Somente 33 participantes justificaram suas respostas, com nove participantes apontando que essa é apenas uma "característica do sujeito". Sete relataram a multideterminação causal, quatro responderam que não faz sentido buscar uma causa, e três responderam "não sei".

Com relação aos sentimentos mais expressivos que os participantes relataram ter em relação aos transexuais, setenta e quatro participantes responderam "respeito" (90,2\%), e 40, admiração (48,8\%). Dez participantes revelaram sentir pena e estranhamento $(12,2 \%)$, e nove, indiferença (11\%). Os sentimentos mais apontados com relação à travestilidade foram respeito (75 participantes, o equivalente à $91,5 \%$ ), e admiração (36 participantes $=43,9 \%$ ). Treze disseram sentir estranhamento e indiferença (15,9\%). Dois relataram pena, um, tristeza, e outro, desprezo. 


\section{Formação e questões diretamente relacionadas à prática profissional}

Metade dos participantes (41) relatou não ter cursado disciplinas que abordassem gênero ou sexualidade na faculdade. Apesar disso, a outra metade diz ter cursado alguma disciplina, sendo 37 participantes $(45,1 \%)$ de ambos os temas, três somente de gênero $(3,7 \%)$ e um somente de sexualidade $(1,2 \%)$. Porém, quando perguntado o nome da disciplina cursada, fica evidenciado que a temática surgiu, muito provavelmente, apenas marginalmente em disciplinas de outras áreas, sendo as palavras "gênero ou sexualidade" presentes no título das disciplinas em apenas 11 dos 36 participantes que responderam à questão, ou seja, o equivalente a menos de um terço do total de respostas. Todos os participantes disseram ter interesse em cursar uma disciplina sobre essas temáticas.

Dos 82 participantes, $35(42,6 \%)$ afirmaram ter lido algum material com embasamento científico sobre LGBTs por exigência de alguma disciplina $(42,7 \%)$, sendo o tipo de material artigos para a maioria (34) desses participantes (41,5\%). Livros ou capítulos de livros e matérias de jornais ou revistas também foram citados por 24 (29,3\%) e 18 (22\%) participantes, respectivamente. Um dado interessante se refere, novamente, ao baixo número de disciplinas com as palavras "gênero" ou "sexualidade" no título (apenas dois participantes, dentre os 26 que afirmaram já ter lido esse tipo de materiais por exigência de alguma disciplina).

Um dado alarmante foi a denúncia de 22 participantes $(26,8 \%)$, que afirmaram que algum professor já deu declarações preconceituosas com relação a LGBTs em sala de aula. Vinte respondentes deram exemplos das condutas preconceituosas e/ou concepções diversas às normatizadas que podem levar à discriminação, que foram categorizadas em: piadas sobre gays/piadas homofóbicas (sete), existência de heterofobia ${ }^{3}$ (três), associação de gênero com orientação sexual (por exemplo, "se um rapaz é feminino, deve ser gay”) (três), patologização sem especificar grupo-alvo (dois), não existência da bissexualidade (dois), patologização da transexualidade (um), e apologia ao estupro (um). Alguns relatos alarmantes seguem: "Disse que bissexualidade não existe e é indecisão e que heterofobia existe"; "Transsexuali- dade é doença/patologia, deve ser curado"; "Insinuou que alguns esportes ou cores não combinam com homens"; "Gente! Relaxa que estupro até que é bom... que mania de dizer que tudo é violência...”.

Em "Você já leu algum material com embasamento científico sobre LGBTs por conta própria?", 51 participantes responderam que $\operatorname{sim}(62,2 \%)$, e os demais não $(31 ; 37,8 \%)$. As justificativas para terem lido foram, em sua maioria, interesse ou curiosidade. Poucos relataram também terem lido por estudarem a temática em projetos de extensão e/ou estágios. Os que responderam não ter lido tais materiais justificaram, na maioria das vezes, pela falta de tempo.

Na questão "Você já leu algum material com embasamento científico sobre gênero e sexualidade por conta própria?", 49 participantes disseram já ter lido sobre ambas as temáticas $(59,8 \%)$; outros oito relataram ter lido somente sobre gênero $(9,8 \%)$, e dois apenas sobre sexualidade $(2,4 \%)$. O restante (23) respondeu não ter lido (28\%). Dos 52 participantes que relataram onde haviam lido, as respostas foram: artigo ou capítulo de livro (24), internet (19), blogs (três), disciplinas (dois), Facebook (dois) e congressos (dois).

Na questão "Você se sentiria constrangido ou incomodado em trabalhar com um paciente/cliente LGBT?", 77 participantes responderam que não $(93,9 \%)$. Quatro disseram que sim, pois se sentem despreparados, uma vez que a formação não contemplou, ou abordou apenas superficialmente essa temática. Um respondente disse que sim, por conta de crenças pessoais: "Talvez me sentiria incapaz de olhar sem julgar, seria um desafio pessoal. Eu teria que avaliar se poderia ajudar a pessoa sem atravessar patologicamente minhas crenças no atendimento".

Para 74 participantes $(90,2 \%)$, não é possível reverter a homossexualidade de um indivíduo em heterossexualidade. Oito participantes $(9,8 \%)$, por outro lado, acreditam que sim. Quando os participantes são perguntados sobre a possibilidade de reverter a heterossexualidade em homossexualidade, o número que responde de maneira negativa cai: 66 respondem não $(80,5 \%)$ e os 16 restantes $\operatorname{sim}(19,5 \%)$. As justificativas fornecidas pelos participantes ao negarem a possibilidade de reversão da homossexualidade se categorizam em: é uma característica do sujeito $(\mathrm{N}=20)$, não faz sentido/é antiético ( $\mathrm{N}=13)$, não é doença para mudar/curar ( $\mathrm{N}=8$ ), não é possível mudar o desejo de

${ }^{3}$ Heterofobia é a crença da existência de preconceito sexual com relação a indivíduos heterossexuais do mesmo modo como ocorre com homossexuais (homofobia). 
alguém, apesar de ser possível modificar o comportamento ( $\mathrm{N}=7)$, a sexualidade é fluída $(\mathrm{N}=6)$, não é algo que se muda ( $\mathrm{N}=6)$, não existem evidências de que seja possível $(\mathrm{N}=5)$, o indivíduo nasceu assim, logo, não se pode mudar $(\mathrm{N}=6)$.

Na pergunta sobre a reversão da heterossexualidade, as respostas se elencam em: é uma característica do sujeito $(\mathrm{N}=17)$, a sexualidade é fluída $(\mathrm{N}=10)$, não é algo que se muda ( $\mathrm{N}=9$ ), não é possível mudar o desejo de alguém, apesar de ser possível modificar o comportamento $(\mathrm{N}=5)$, não é doença para mudar/curar $(\mathrm{N}=5)$, o indivíduo nasceu assim, logo, não se pode mudar ( $\mathrm{N}=3)$, não faz sentido/é antiético $(\mathrm{N}=2)$.

Todos os participantes alegaram ser importante que o curso de Psicologia trabalhe com a temática de gênero. Entre as explicações, apareceram o gênero como questão central de sofrimento por vários indivíduos, a necessidade de se estudar algo que é considerado central para a identidade dos indivíduos, além de questões como a especificidade dos LGBTs, os diferentes conceitos de gênero existentes e a importância de estar atualizado, e a relação das questões de gênero com o machismo, a misoginia e a homofobia. Todos os participantes também consideraram relevante estudar sexualidade na graduação. As explicações foram bastante semelhantes às fornecidas na questão sobre a importância de se estudar gênero (por exemplo, a sexualidade como questão central de sofrimento por vários indivíduos, e a necessidade de se estudar algo que é considerado central para a identidade dos indivíduos). Todos os participantes também demonstraram interesse em cursar uma disciplina ou curso de extensão cuja temática fosse de gênero e sexualidade.

\section{Conhecimento das orientações das autarquias responsáveis pela normatização e fiscalização do exercício profissional do psicólogo a respeito da diversidade sexual e de gênero}

Na pergunta "De acordo com as orientações do Conselho Federal de Psicologia, o psicólogo pode tentar reverter a homossexualidade de um indivíduo em heterossexualidade?", 75 responderam que não $(91,5 \%)$. Os demais (sete) responderam não saber $(8,5 \%)$. A mesma pergunta, substituindo "homossexualidade" por "bissexualidade", gerou respostas semelhantes: 69 respostas negativas $(84,1 \%)$, e 13 "não sei" (15,9\%).
Com relação à definição de homossexualidade de acordo com as declarações mais recentes do CFP, 63 participantes responderam que é "uma orientação sexual” (89\%), e 19 disseram que é uma identidade de gênero (23,3\%); as demais opções de resposta (doença, distúrbio, perversão, transtorno de personalidade, patologia e transtorno de identidade de gênero) foram escolhidas uma vez cada, totalizando $7,2 \%$ das respostas. As mesmas respostas foram obtidas quando se perguntou o que seria a heterossexualidade, de acordo com o CFP.

Na questão "De acordo com as declarações mais recentes do CFP, o que é a transexualidade?", 67 participantes responderam que é uma identidade de gênero (81,7\%); 19 disseram ser um transtorno de identidade de gênero (23,2\%), e 11 participantes, uma orientação sexual (13,4\%). Três participantes responderam que é uma doença, e outros três, um distúrbio. Dois afirmam ser uma patologia, um, perversão, e outro, transtorno de personalidade. Portanto, em conjunto, a patologização da transexualidade foi obtida em $35,4 \%$ das respostas.

Com relação à travestilidade, as respostas foram semelhantes, numericamente falando: Sessenta e cinco participantes responderam identidade de gênero (79,3\%); 14 responderam transtorno de identidade de gênero $(17,1 \%)$, e 12 , orientação sexual $(14,6 \%)$. Quatro afirmaram ser um transtorno de personalidade; três, uma doença, e outros três, uma patologia. Dois assinalaram distúrbio, e um respondeu perversão. Deste modo, em conjunto, 33\% das respostas apontaram a travestilidade como uma doença.

Por fim, quando questionados se, enquanto futuros psicólogos, estão preparados para lidar com LGBTs, 48 participantes alegaram estarem preparados $(58,50 \%)$. Quatro admitiram estar parcialmente preparados $(4,87 \%)$, e cinco disseram não saber se estão preparados ou não (6,09\%). Dezoito afirmaram não estar preparados (21,95\%), e os demais relataram que até o final do curso devem estar preparados (sete participantes $=8,53 \%$ ). Dos que afirmaram estar preparados, as justificativas foram as seguintes: nove indicaram que leram sobre o assunto (18,75\%), oito indicaram ser LGBTs $(16,66 \%)$; seis afirmaram ter contato com indivíduos LGBTs (12,50\%); oito responderam que estão preparados pois o mais importante seria o respeito e a empatia $(16,66 \%)$; quatro responderam que estariam aptos por serem LGBTs $e$ terem lido sobre o assunto $(8,33 \%)$, ou por terem 
contato com LGBTs $e$ terem lido sobre o assunto (cinco participantes; 10,41\%). Com relação aos que disseram não se sentir preparados, a maioria (12; $66,66 \%)$ relatou que o curso não abordou a temática, ou abordou apenas marginalmente.

\section{Discussão}

Os objetivos da presente pesquisa foram verificar os conhecimentos de alunos de Psicologia interessados na temática de gênero e sexualidade sobre indivíduos LGBTs, especialmente com relação às recomendações do CFP relativas à diversidade sexual e de gênero, e também buscar relações entre o interesse dos alunos nas temáticas e concepções menos patologizantes de gêneros e sexualidades dissidentes. Com relação ao último objetivo, este é extremamente importante, uma vez que existe um argumento de que "os alunos com interesse nas temáticas de gênero e sexualidade buscarão informações que os capacitarão para atuar como psicólogos, clínicos ou não, com indivíduos LGBTs, sendo as disciplinas de gênero e sexualidade, ou que abordem especificamente a diversidade sexual e de gênero, portanto, desnecessárias ou não prioritárias". Este argumento tem surgido em contextos onde os efeitos (especialmente negativos) do desconhecimento sobre a diversidade sexual e de gênero são evidenciados, mas a grade curricular das disciplinas do curso de Psicologia (mas não restrita a este) está fechada e segue um padrão estabelecido há anos, com poucas mudanças. Todavia, como os dados mostraram, apesar de a amostra ser composta por alunos que, de fato, demonstraram ter interesse nas temáticas de gênero e sexualidade, isso não se mostrou suficiente para que eles demonstrassem acompanhar as discussões relativas particularmente aos LGBTs, como saber quais são as terminologias mais adequadas e, especialmente, conhecer os pronunciamentos de autarquias da Psicologia, como o Conselho Federal, a respeito das concepções e práticas recomendadas à população LGBT.

Foi possível verificar que, apesar de os conhecimentos dos alunos serem, em geral, consistentes com as concepções correntes acerca da diversidade sexual (pelo menos da abordada na presente pesquisa), com relação à diversidade de gênero, foi possível verificar que a maioria dos participantes possuem dúvidas e concepções divergentes àquelas normatizadas para o exercício dos profissionais da Psicologia sobre o que seriam a transexualidade e travestilidade, como evi- denciado em diversas pesquisas (por exemplo, Araujo et al., 2007; Dinis, 2011; Lima \& Uziel, 2013; Santos et al., 2011; Silva, 2014). Isso fica bastante claro, por exemplo, quando se compara a porcentagem de alunos que acreditam que a homossexualidade é considerada uma patologia (doença, distúrbio, perversão e/ou transtorno da personalidade) pelo CFP, em comparação com a transexualidade ou travestilidade: enquanto nenhum participante acredita que o CFP considera a homossexualidade uma patologia, $35,4 \%$ dos alunos acreditam que a transexualidade seja considerada uma patologia, e 33,0\% dos participantes creem que a travestilidade também o seja. Isso mostra que, embora os alunos tenham feito leituras sobre o tema, sejam em disciplinas ou por conta própria, tais materiais podem vir das mais variadas fontes, muitas delas fontes que patologizam a diversidade sexual e de gênero e, portanto, são contrárias às recomendações do CFP e das discussões das ciências sociais (por exemplo, Britzman, 1996; Butler, 2001, 2003; Louro, 2001, 2008; Weeks, 2000).

A forma como alguns participantes responderam também pode indicar o que os participantes aprenderam sobre as temáticas. Por exemplo, alguns participantes utilizaram a palavra "gênero", e outros, "sexo", em suas definições de orientação sexual, assim como as palavras (sexo/gênero) "diferente" e (sexo/ gênero) "oposto" foram utilizadas por diferentes participantes ao explicarem o que seria a transexualidade e travestilidade. $\mathrm{O}$ fato de alguns participantes escreverem sobre um "gênero diferente ao próprio" mostra que a construção de gêneros opostos, compulsória em nossa sociedade, não é vista mais como a única alternativa possível, ou seja, esses participantes foram expostos a literaturas que mostram que em diferentes culturas, e ao longo dos tempos, identidades de gênero não binárias sempre existiram (por exemplo, hijras, berdaches, virgens por juramento), e/ou que a concepção de dois gêneros opostos e estáveis é uma criação do século XVIII (Laqueur, 1990). Em comparação, o uso de "gênero oposto" parece refletir a aprendizagem que ocorre desde crianças, de que existem apenas dois gêneros, opostos e incomensuráveis (o modelo de dois sexos - Laqueur, 1990), o que pode causar, consequentemente, estranhamento e/ou atitudes negativas com relação às identidades de gênero não binárias ou ao trânsito de gêneros.

O fato de que, na pergunta sobre o que os participantes entendem por orientação sexual, o número 
de justificativas foi mais baixo que o número total de respondentes da pesquisa (apenas sete respostas para 82 participantes) também mostra que o conhecimento dos participantes é, ainda, superficial, uma vez que esta definição é bastante geral, englobando, por sua vez, a hetero, homo e bissexualidade (e outras mais, como a assexualidade). Isso é também evidenciado quando os participantes confundem orientação sexual com identidade de gênero nas questões sobre o que seria a homossexualidade, e especialmente, a transexualidade e travestilidade.

No que diz respeito a relação entre cursar disciplinas que abordassem a temática de gênero e sexualidade e demonstrar maior conhecimento das concepções correntes sobre o tema e/ou demonstrar concepções menos patologizantes, os dados da presente pesquisa mostraram que cursar disciplinas que abordaram as temáticas de gênero e sexualidade, de maneira geral, e/ou especificamente que abordassem LGBTs não foi suficiente para que suas concepções se alinhassem às emitidas pelo CFP, especialmente nas perguntas sobre as identidades trans. À primeira vista, pode parecer que a inclusão dessas disciplinas não se correlaciona, portanto, com concepções menos patologizantes e/ou mais coerentes com as concepções emitidas pelo CFP e instituições afins (por exemplo, Associação Americana de Psicologia). Entretanto, como evidenciado na sessão de resultados, é bastante provável que esses conteúdos apareceram nestas disciplinas de maneira superficial, uma vez que as palavras "gênero" ou "sexualidade" apareceram no título de tais disciplinas de apenas 11 participantes, o equivalente a apenas $13,4 \%$ dos respondentes da pesquisa. Uma limitação do presente estudo foi a não comparação entre a grade curricular e/ou planos das disciplinas dos cursos de Psicologia dos participantes e suas respostas no questionário. Apesar de ser um objetivo secundário, tal empreitada resultaria em outro artigo. Assim, utilizou-se, para comparação, o fato de os alunos terem ou não cursado tais disciplinas, como evidenciado em uma das perguntas do questionário. Sugere-se, contudo, que estudos futuros realizem esse tipo de análise comparativa.

\section{Psicologia, currículo e prática profissional}

Até que ponto o interesse pessoal por uma temática específica garante o acesso a informações de qualidade e conhecimento concernentes a essa temática? Tratando-se de uma temática que diz respeito à superação de desigualdades sociais e a promoção de direitos caberia esperar que a motivação para o desenvolvimento deste conhecimento partisse de um interesse pessoal? Trata-se realmente de uma escolha individual entre conhecer ou não conhecer, obter ou não obter informações sobre determinado assunto ou é a própria noção de interesse pessoal que deve ser revisada?

Se o conhecimento ou temática em questão integra os conhecimentos relevantes para o bom desempenho de uma profissão, tal conhecimento não deveria, obrigatoriamente, fazer parte da grade curricular para a formação nesta profissão? E se o desconhecimento de determinada temática estivesse relacionado com atitudes preconceituosas e discriminação com relação a uma população específica, isso não seria justificativa suficiente para a inclusão desses temas no currículo de formação? Por fim, cabe-nos questionar ainda: até que ponto é possível definir aquilo que nomeamos como interesse pessoal, distinguindo-o do contexto em que foi construído? Em outras palavras, se assumirmos que interesses pessoais são também construídos pela cultura na qual se inserem, e que esta, por sua vez, possui um histórico de exclusão/rejeição de determinados temas e, porque não dizer, sujeitos ligados a esses temas, é preciso elaborar formas de alterar interesses pessoais em favor de uma sociedade igualitária e democrática.

Em seu artigo "Problemas de gênero na e para a democracia”, a professora, filósofa e feminista Carla Rodrigues (2017) utiliza-se da conceituação de outro filósofo, o franco-argelino Jacques Rancière, que define democracia como "o poder de qualquer um, a indiferença das capacidades para ocupar as posições de governante e de governado" (p.30). Para a autora, vivemos atualmente, ao contrário do que propõe Rancière, uma delimitação rigidamente definida daqueles que podem governar (sumariamente homens brancos e heterossexuais) e dos que devem ser governados, "aqueles cujas marcações (de gênero, raça, classe etc.) os colocam necessariamente em posição de subalternidade" (Rodrigues, 2017, p. 31, parênteses nossos). Defender a democracia, neste sentido, passaria, necessariamente, por uma revisão dos lugares de privilégio historicamente construídos e em contrapartida, pela promoção e garantia de direitos a todos aqueles que ficaram à margem de tais privilégios. 
A Psicologia, neste sentido, possui importante papel, não apenas na promoção e garantia de direitos, mas principalmente na restituição do status social dado a sujeitos com gêneros dissidentes e de orientações sexuais não heterossexuais. Cabe explicitar que os saberes psi foram um dos responsáveis pela patologização e marcação de sujeitos como doentes mentais e transtornados de gênero durante muitos anos (por exemplo, Baptista, 1999; Borges, 2009; Borges et al., 2013; Dinis, 2011; Guimarães, 2009; Oliveira, 2010). As campanhas pela despatologização das identidades trans, bem como as demais notas emitidas pelo CFP fazem eco às mudanças sociais amplas que vem ocorrendo globalmente, principalmente no que se refere a maior visibilidade das diferentes formas de viver e expressar a sexualidade e a identidade de gênero, e da ascensão dos indivíduos LGBTs como sujeitos de direito (vide mudanças em legislações, tais como a união estável, o casamento, a adoção, o uso do nome social etc.).

Além disso, há, de modo geral, uma mudança no referencial epistemológico a partir do qual se compreende as identidades. A flexibilização da distinção binária entre normal e patológico desatualiza qualquer modelo que classifique e categorize sujeitos rigidamente. Passa-se, pelo contrário, a se trabalhar com uma visão relacional da formação das identidades, que considera as contingências nas quais as identidades são formadas. Tais mudanças devem refletir no currículo das universidades, que necessariamente devem abordar questões de gênero e sexualidade.

Os dados mais recentes sobre a violência contra LGBTs (Grupo Gay da Bahia [GGB], 2016) mostram que, a cada 25 horas, um indivíduo LGBT é morto no Brasil. Somente no ano passado, 343 LGBTs foram mortos. Um dado ainda mais preocupante é que o número de mortos de LGBTs no Brasil vem crescendo ao longo dos anos, e os dados apresentados no relatório se referem apenas aos casos que foram notificados, o que evidencia que o problema é muito pior. Como consta no relatório, "matam-se mais homossexuais aqui do que nos 13 países do Oriente e África onde há pena de morte contra os LGBTs". O Brasil segue sem a aprovação do projeto de lei que criminalizaria a homofobia, equiparando a homofobia ao racismo. A tendência de mortes se mantém em 2017: nos primeiros 22 dias do mês de janeiro, foram documentados mais 23 assassinatos de LGBTs. É importante salientar que os números tratados se referem apenas a formas de violência letais: as formas de violência não letais, como espancamentos, expulsão de casa e/ou de ambientes públicos, como bares, banheiros etc., agressões verbais, estupro "corretivo", e muitas outras formas ocorrem diariamente e possuem efeitos destrutivos na autoestima e em outros elementos da saúde física e psicológica das vítimas.

Dinis (2011), escrevendo sobre a relação entre a homofobia e a educação, vê "a omissão do tema da diversidade sexual e de gênero no currículo escolar como forma oculta de homofobia e da cumplicidade de educadores e educadoras com essa violência (p. 39)". Concordamos com a posição de Dinis, e a ampliamos ao dizer que os silenciamentos e a exclusão de algumas disciplinas em detrimento de outras, na graduação dos cursos de Psicologia também se configuram como formas ocultas de violência que permitem, em última instância, a existência de um ambiente hostil aos indivíduos LGBTs, onde as concepções patologizantes são utilizadas como justificativas para violentar indivíduos que são desprovidos de suas humanidades, ao serem considerados anormais.

A formação deficitária, no sentido de não prover oportunidades de ensino e discussão de temas acerca das questões de gênero e sexualidade pode ter consequências negativas para os indivíduos cujo gênero e/ ou orientação e/ou prática sexual não se enquadra nos modelos hegemônicos, uma vez que auxilia na legitimação do preconceito e da discriminação, independente da área onde o profissional de Psicologia atue, e também tem produtos negativos para o próprio profissional, que não se sente preparado para lidar com tais indivíduos, precisando encaminhar esses casos, ou ainda pior, quando o profissional faz declarações de cunho patologizante e/ou propondo terapias que supostamente irão "curar" a homossexualidade de um indivíduo (Lhullier, Müller, Bonassi, \& Longhini, 2013). Além disso, o não cumprimento das normas de atuação publicadas pelas autarquias responsáveis pela normatização e fiscalização do exercício dos profissionais da Psicologia pode ser penalizado, inclusive pela cassação do registro profissional do infrator (CRP-SP, 2008), de modo que o conhecimento de tais orientações é imperativo para a prática ética dos profissionais da área.

\section{Considerações finais}

A presente pesquisa amplia a literatura sobre o tema ao mostrar que as concepções de alunos de graduação em Psicologia de diversas instituições de 
ensino brasileiras são divergentes com relação às normativas emitidas por autarquias como o CFP, especialmente com relação às identidades trans, e que o interesse nas temáticas de gênero e sexualidade, avaliado inclusive pela leitura de materiais científicos sobre o tema não é suficiente para que tais alunos saibam as concepções correntes na área. Além das informações coletadas, o presente trabalho faz uma análise breve, porém crítica, questionando a ausência de tais temáticas em diversos cursos de Psicologia brasileiros, contrastando com o número de mortes de LGBTs, a grande maioria sendo crimes de ódio.

Como justificar a não inclusão das temáticas de gênero e sexualidade quando se tem um número tão alto de mortes de indivíduos LGBTs (e de não LGBTs, confundidos com os primeiros), além de pesquisas mostrando que tanto alunos quanto docentes da área possuem concepções patologizantes a respeito da diversidade sexual e de gênero, concepções essas que possuem implicações diretas na saúde mental de indivíduos LGBTs e outros cuja performance de gênero não é considerada binária e/ou estanque, como os indivíduos heterossexuais que são confundidos com gays, por mostrarem trejeitos considerados femininos? A responsabilidade dos cursos de Psicologia (mas não restrita a ele) na manutenção da homofobia e das mortes de LGBTs deve ser evidenciada, e a hora de construir disciplinas, promover oficinas, cursos e outras formas de transmissão do conhecimento, salientando o caráter compulsório da heterossexualidade e o caráter construído da suposta coerência entre sexo, gênero e orientação sexual é agora!

\section{Referências}

Araujo, L. F., Oliveira, J. S. C., Sousa, V. C., \& Castanha, A. R. (2007). Adoção de crianças por casais homoafetivos: Um estudo comparativo entre universitários de direito e psicologia. Psicologia e Sociedade, 19(2), 95-102. https://doi. org/10.1590/S0102-71822007000200013

Aguiar, W. M. J. (2003, novembro/dezembro). Atitude religiosa e científica: Distinção é exigência para a prática profissional. Jornal PSI, (138). Recuperado de http://www.crpsp.org.br/portal/comunicacao/jornal_crp/138/ frames/fr_questoes_eticas.aspx

Baptista, L. A. S. (1999). A atriz, o padre e a psicanalista: Os amoladores de faca. In L. A. S. Baptista, A cidade dos sábios: Reflexoes sobre a dinamica social nas grandes cidades (pp. 45-49). São Paulo, SP: Summus.

Bardin, L. (1979). Análise de conteúdo. Lisboa: 70.

Borges, L. S. (2009). (Homo)sexualidades e formação profissional: Desafios para a psicologia. Revista Eletrônica de Psicologia e Políticas Públicas, 1(1), 146-157.

Borges, L. S., Canuto, A. A. A., Oliveira, D. P., \&Vaz, R. P. (2013). Abordagens de gênero e sexualidade na psicologia: Revendo conceitos, repensando práticas. Psicologia: Ciência e Profissão, 33(3), 730-745. https://doi.org/10.1590/ S1414-98932013000300016

Brasil. Ministério do Trabalho. (1992). Atribuiçães profissionais do psicólogo no Brasil: Contribuição do Conselho Federal de Psicologia ao Ministério do Trabalho para integrar o catálogo brasileiro de ocupações. Brasília, DF: o autor. Recuperado de http://site.cfp.org.br/wp-content/uploads/2008/08/atr_prof_psicologo.pdf

Britto, P., \& Reis, L. (2015, junho 25). Por pressão, planos de educação de 8 estados excluem 'ideologia de gênero'. Uol Educação. Recuperado de http://wwwl.folha.uol.com.br/educacao/2015/06/1647528-por-pressao-planos-de-educacao-de-8-estados-excluem-ideologia-de-genero.shtml

Britzman, D. P. (1996). O que é esta coisa chamada amor: Identidade homossexual, educação e currículo. Educação e Realidade, 21(1), 71-96.

Butler, J. (2001). Corpos que pesam: Sobre os limites discursivos do sexo. In G. L. Louro (Org.), O corpo educado: Pedagogias da sexualidade (pp. 151-172). Belo Horizonte, MG: Autêntica.

Butler, J. (2003). Problemas de gênero: Feminismo e subversão da identidade. Rio de Janeiro, RJ: Civilização Brasileira.

Conselho Federal de Psicologia - CFP. (2013). Nota técnica sobre processo transexualizador e demais formas de assistência às pessoas trans. Brasília, DF: o autor. Recuperado de: http://site.cfp.org.br/wp-content/uploads/2013/09/ Nota-t\%C3\%A9cnica-processo-Trans.pdf 
Conselho Regional de Psicologia de São Paulo - CRP-SP. (1999). Homossexualidade não pode ser vista como desvio. São Paulo, SP: o autor. Recuperado de http://www.crpsp.org.br/portal/comunicacao/jornal_crp/115/frames/ fr_normatizacao.aspx

Conselho Regional de Psicologia de São Paulo - CRP-SP. (2005). Resoluções do CFP ainda são pouco abordadas na formação profissional. São Paulo, SP: o autor. Recuperado de http://www.crpsp.org.br/portal/comunicacao/ jornal_crp/145/frames/fr_formacao.aspx

Conselho Regional de Psicologia de São Paulo - CRP-SP. (2007). Psicólogo não deve tratar homossexualidade como distúrbio. São Paulo, SP: o autor. Recuperado de http://www.crpsp.org.br/portal/comunicacao/jornal_crp/150/ frames/fr_orientacao.aspx

Conselho Regional de Psicologia de São Paulo - CRP-SP. (2008). Orientação sexual e questões de gênero: A regra é clara. São Paulo, SP: o autor. Recuperado de http://www.crpsp.org.br/portal/comunicacao/jornal_crp/156/ frames/fr_questoes_eticas.aspx

Conselho Regional de Psicologia de São Paulo - CRP-SP. (2013). Projeto da cura gay entra na pauta da comissão de direitos humanos. São Paulo, SP: o autor. Recuperado de http://www.crpsp.org.br/portal/midia/fiquedeolho_ver.aspx?id=605

Dinis, N. F. (2011). Homofobia e educação: Quando a omissão também é signo de violência. Educar em Revista, (39), 39-50. https://doi.org/10.1590/S0104-40602011000100004

Dinis, N. F. (2012). Discursos sobre homossexualidade e gênero em um curso de formação em psicologia. Educação Temática Digital, 14(1), 62-75. https://doi.org/10.20396/etd.v14i1.1241

Grupo Gay da Bahia - GGB. (2016). Relatório de assassinatos de LGBTs no Brasil no ano de 2016. Salvador, BA: o autor. Recuperado de https://homofobiamata.files.wordpress.com/2017/01/relatc3b3rio-2016-ps.pdf

Guimarães, A. F. P. (2009). O desafio histórico de “tornar-se um homem homossexual”: Um exercício de construção de identidades. Temas em Psicologia, 17(2), 553-567.

Lacerda, M., Pereira, C., \& Camino, L. (2002). Um estudo sobre as formas de preconceito contra homossexuais na perspectiva das representações sociais. Psicologia: Reflexão e Crítica, 15(1), 165-178. https://doi.org/10.1590/ S0102-79722002000100018

Laqueur, T. (1990). La construcción del sexo: Cuerpo y género desde los griegos hasta Freud (E. Portella, Trad.). Madri: Harvard University.

Lima, M. L. C., \& Uziel, A. P. (2013). Gênero e sexualidade na formação e prática profissional em psicologia. In: Conselho Federal de Psicologia - CFP (Ed.), Psicologia, uma profissão de muitas e diferentes mulheres (pp. 51-76). Brasília, DF: o autor.

Lhullier, L. A., Müller, R. F., Bonassi, B. C., \& Longhini, G. D. N. (2013). Introdução: A pesquisa, seus antecedentes e a proposta que a orientou. In: Conselho Federal De Psicologia - CFP (Ed.), Psicologia, uma profissão de muitas e diferentes mulheres (pp. 11-20). Brasília, DF: o autor.

Louro, G. L. (2001). Currículo, género e sexualidade. Porto: Porto.

Louro, G. L. (2008). Um corpo estranho: Ensaios sobre sexualidade e teoria queer. Belo Horizonte, MG: Autêntica.

Nogueira, C. (2001). Contribuições do construcionismo social a uma nova psicologia do gênero. Cadernos de Pesquisa, (112), 137-153.

Nuernberg, A. H. (2005). Gênero no contexto da produção científica brasileira em psicologia (Tese de doutorado). Centro de Filosofia e Ciências Humanas, Universidade Federal de Santa Catarina, Florianópolis, SC, Brasil.

Oliveira, J. M. (2010). Orientação sexual e identidade de gênero na psicologia. In C. Nogueira, \& J. M. Oliveira (Eds.), Estudo sobre a discriminação em função da orientação sexual e da identidade de gênero (pp. 19-44). Lisboa: Clássica.

Resolução $n$. 1, de 22 de março de 1999. Estabelece normas de atuação para os psicólogos em relação à questão da orientação sexual. Brasília, DF: Conselho Federal de Psicologia. Recuperado do de: http://site.cfp.org.br/ wp-content/uploads/1999/03/resolucao1999_1.pdf

Rodrigues, C. (2017). Problemas de gênero na e para a democracia. Ciência e Cultura, 69(1), 30-34. https://doi. org/10.21800/2317-66602017000100013 
Santos, C. B., Costa, A. B., Carpenedo, M., \& Nardi, H. C. (2011). A diversidade sexual no ensino de psicologia: O cinema como ferramenta de intervenção e pesquisa. Sexualidad, Salud y Sociedad, (7), 127-141. https://doi. org/10.1590/S1984-64872011000200006

Silva, R. T. (2014). Percepções sobre gênero e diversidade sexual produzidas por estudantes de psicologia da Universidade Federal do Rio Grande/FURG (Trabalho de conclusão de curso). Universidade Federal do Rio Grande, Rio Grande, RS, Brasil.

Souza, E. L., Silva, J. P., \& Santos, C. (2017). Representações de docentes acerca da diversidade sexual e homofobia. Revista Estudos Feministas, 25(2), 519-544. https://doi.org/10.1590/1806-9584.2017v25n2p519

Stern, F. L. (2006). A visão dos futuros terapeutas sobre a homossexualidade em atendimento. Seminário fazendo gênero: Simpósio Temático: Articulando gênero e geração aos estudos de saúde e sexualidade. Florianópolis, SC, Brasil, 14. Recuperado de http://www.fazendogenero.ufsc.br/7/artigos/W/Wedekin_Stern_14.pdf

Vieira, L. F., Hernández, J. G., \& Uziel, A. P. (2013). As psicólogas e a homossexualidade: Noções, princípios e exercício profissional. In: Conselho Federal de Psicologia - CFP (Ed.), Psicologia, uma profissão de muitas e diferentes mulheres (pp. 121-148). Brasília, DF: o autor.

Weeks, J. (2000). O corpo e a sexualidade. In: G. L. Louro (Org.), O corpo educado: Pedagogias da sexualidade (pp. 35-82). Belo Horizonte, MG: Autêntica.

\section{Apêndice}

\section{Questionário acerca de conhecimentos sobre gênero e sexualidade}

O objetivo dessa pesquisa é identificar as concepções de estudantes de Psicologia sobre gênero e sexualidade. Fique tranquilo. Suas respostas serão utilizadas somente em conjunto, e é garantido o sigilo de suas informações individuais. Por favor, responda com sinceridade às questões.

OBSERVAÇÃO: Ao longo do questionário, o termo homossexual se refere a gays $e$ lésbicas e o termo LGBT se refere a lésbicas, gays, bissexuais, travestis e transexuais.

1. O que você entende por orientação sexual?

2. Bissexual significa...

3. Heterossexual significa...

4. Homossexual significa...

5. O que é a homossexualidade para você? Escolha quantas alternativas se aplicarem*:

( ) Um desvio de conduta

( ) Uma doença

( ) Uma orientação sexual

( ) Uma escolha

( ) Um estilo de vida

() Outro:

6. Você acha que a homossexualidade é algo que tem uma causa ${ }^{1}$ específica\#?

( ) Sim. Qual?

( ) Abusos sexuais/traumas sofridos na infância/conflitos parentais

( ) Problemas hereditários/má formação gestacional durante o período da gestação/disfunções hormonais

( ) Falta de respeito/desvio de conduta/falta de valores morais

\footnotetext{
${ }^{1}$ As perguntas que questionavam sobre uma causa específica para as orientações sexuais foram incluídas no questionário com o intuito de identificar possíveis fontes de aprendizagem (por exemplo, orientação teórica, religião) entre as orientações sexuais não heterossexuais e concepções negativas dessas.

* As mesmas questões foram feitas substituindo a palavra "homossexualidade" por "heterossexualidade".

\# As mesmas questões foram feitas substituindo a palavra "homossexualidade/homossexuais" por "heterossexualidade/heterossexuais",

"transexualidade/transexuais" e "travestilidade/travestis".
} 
( ) Falta de fé/descumprimento da palavra de Deus/fraqueza espiritual

( ) Psicose/questões relacionadas à má resolução do complexo de Édipo

( ) Não sei/não tenho opinião formada sobre o assunto

() Outra. Especifique:

( ) Não. Justifique:

7. Marque com um $\mathrm{X}$ os sentimentos mais expressivos que você tem em relação aos homossexuais (Marque quantas alternativas se aplicarem)\#:
( ) Admiração
() Raiva
( ) Tristeza
() Respeito
( ) Desprezo
() Indiferença
( ) Ternura
() Pena
() Orgulho
() Estranhamento

8. Qual situação deixaria você mais constrangido (a) com relação aos homossexuais? Marque quantas alternativas se aplicarem.

( ) Ter um amigo homossexual assumido

( ) Ter uma amiga lésbica assumida

( ) Ver dois homens se beijando

() Ver duas mulheres se beijando

( ) Ter um filho homossexual

( ) Ter uma filha lésbica

( ) Ter um chefe homossexual

() Ter uma chefe lésbica

( ) Morar com gays

( ) Morar com lésbicas

( ) Nenhuma das situações acima me deixa constrangido(a)

9. Você é a favor do casamento entre homossexuais? Justifique*.

() Sim

( ) Não

() Indiferente

( ) Não tenho opinião formada

10. Você é a favor da adoção por homossexuais? Justifique*.

() Sim

( ) Não

() Indiferente

( ) Não tenho opinião formada

11. É possível reverter a homossexualidade de um indivíduo em heterossexualidade? Explique.

() $\operatorname{Sim}$

( ) Não

12. É possível reverter a heterossexualidade de um indivíduo em homossexualidade? Explique.

( ) $\mathrm{Sim}$

( ) Não

13. O que você entende por transexualidade?

14. O que você entende por travestilidade? 


\section{Questões sobre a Formação Acadêmica}

1. Instituição em que estuda (e região do Brasil):

2. Ano do curso:

3. Você já cursou alguma disciplina que abordou a temática de gênero ou sexualidade durante a graduação?

() Sim, mas somente de gênero - Nomes das disciplinas:

() Sim, mas somente de sexualidade - Nomes das disciplinas:

() Sim, de ambos os temas - Nomes das disciplinas:

( ) Não. Gostaria de cursar?

() Sim

( ) Não

4. Você já leu algum material com embasamento científico sobre LGBTs por exigência de alguma disciplina? ( ) Sim

Que tipo de material e disciplina?

\section{() Artigo}

() Matéria de jornal ou revista

() Livro/capítulo de livro

( ) Outro? Qual:

Disciplina (s):

( ) Não

5. Durante seus anos na faculdade, algum professor demonstrou alguma postura ou fez alguma declaração preconceituosa sobre LGBTs em sala de aula?

( ) Sim

Por favor, dê alguns exemplos dessas condutas preconceituosas:

( ) Não

( ) Não me lembro

6. Você se sentiria constrangido ou incomodado em trabalhar com um paciente/cliente LGBT? Justifique sua resposta. () $\mathrm{Sim}$

( ) Não

7. Se você pudesse, evitaria atender LGBTs? Justifique sua resposta.

() Sim

( ) Não

8. Você já leu algum material com embasamento científico sobre LGBTs por conta própria?

() Sim. Por quê?

( ) Não. Por quê?

9. Você já leu algum material com embasamento científico sobre gênero e sexualidade por conta própria?

( ) Sim, somente sobre gênero. Onde?

( ) Sim, somente sobre sexualidade. Onde?

( ) Sim, sobre ambas temáticas. Onde?

( ) Não

10. Você acha relevante o curso de Psicologia trabalhar a temática de gênero² durante a graduação? Justifique.

() Sim

( ) Não

11. De acordo com as orientações do Conselho Federal de Psicologia, o psicólogo pode tentar reverter a homossexualidade de um indivíduo em heterossexualidade?

() Sim

( ) Não

( ) Não sei

${ }^{2}$ A mesma pergunta foi feita substituindo "gênero" por "sexualidade". 
12. De acordo com as orientações do Conselho Federal de Psicologia, o psicólogo pode tentar modificar a bissexualidade de um indivíduo para a heterossexualidade?

() $\operatorname{Sim}$

( ) Não

( ) Não sei

13. Você acredita que, enquanto futuro psicólogo/a, estará preparado para lidar com LGBTs?

() Sim. Por quê?

( ) Não. Por quê?

14. De acordo com as declarações mais recentes do Conselho Federal de Psicologia, o que é a homossexualidade ${ }^{3}$ ? Marque quantas se aplicarem:

() Doença

( ) Distúrbio

() Identidade de gênero

( ) Perversão

( ) Orientação sexual

( ) Transtorno de personalidade

( ) Patologia

( ) Transtorno de identidade de gênero

15. Você tem interesse em realizar uma disciplina ou curso de extensão que aborde a temática de gênero e sexualidade? Por quê?

() $\mathrm{Sim}$

( ) Não

\section{Questionário de Caracterização dos Participantes}

Esse breve questionário busca informações que nos ajudam a entender melhor as relações entre as atitudes dos indivíduos e a história de vida destes. Suas respostas serão utilizadas somente em conjunto. Por favor, responda com sinceridade às questões.

1. Qual sua idade em anos?

2. Sexo assignado no nascimento:

() Masculino

() Feminino

3. Identidade de gênero:

() Masculino

() Feminino

() Gênero não binário

() Outro. Qual?

4. Orientação Sexual:

() Heterossexual, sente-se atraído predominantemente por pessoas do sexo "oposto"

( ) Homossexual, sente-se atraído predominantemente por pessoas do mesmo sexo

( ) Bissexual, sente-se atraído por pessoas dos dois sexos

( ) Assexual, não sente-se atraído sexualmente por sexo algum

() Outra. Qual?

5. Religião:

( ) Católica

( ) Protestante? Qual:

( ) Espírita (Kardecismo)

( ) Testemunha de Jeová

${ }^{3}$ A pergunta foi repetida, substituindo a palavra "homossexualidade" por "transexualidade", e em seguida, por "travestilidade”. 

( ) Umbanda/Candomblé
() Judeu
( ) Ateu
( ) Agnóstico
() Outra? Qual:

\section{Táhcita Medrado Mizael}

Doutoranda em Psicologia pela Universidade Federal de São Carlos (UFSCar), São Carlos - SP. Brasil.

E-mail: tahcitammizael@gmail.com

(iD) https://orcid.org/0000-0002-5543-1188

\section{Ariane Rico Gomes}

Graduanda em Psicologia pela Universidade Federal de São Carlos (UFSCar), São Carlos - SP. Brasil.

E-mail: arianerico2010@gmail.com

(iD https://orcid.org/0000-0002-4898-9693

\section{Paula Pizzirani Marola}

Mestranda em desenvolvimento humano e tecnologias pela Universidade Estadual Paulista Júlio de Mesquita Filho (UNESP), Rio Claro - SP. Brasil.

E-mail: paulamarola@gmail.com

(iD) https://orcid.org/0000-0002-8876-7083

Endereço para envio de correspondência:

Universidade Federal de São Carlos, Departamento de Psicologia, Laboratório de Estudos do Comportamento Humano (LECH) - Edifício Carolina Bori. Rodovia Washington Luís, km 235, Caixa Postal: 676, CEP 13565-905. São Carlos - SP. Brasil.

Recebido 15/07/2017

Reformulado $07 / 05 / 2018$

Aceito 05/07/2018

Received $07 / 15 / 2017$

Reformulated $05 / 07 / 2018$

Approved 07/05/2018

Recibido 15/07/2017

Reformulado 07/05/2018

Aceptado 05/07/2018

Como citar: Mizael, T, M.; Gomes, A. R., \& Marola, P. P. (2019). Conhecimentos de estudantes de Psicologia sobre normas de atuação com indivíduos LGBTs. Psicologia: Ciência e Profissão, 39, 1-20. https://doi.org/10.1590/1982-3703003182761

How to cite: Mizael, T, M.; Gomes, A. R., \& Marola, P. P. (2019). Psychology students' knowledge concerning guidelines for psychological practice with LGBTs. Psicologia: Ciência e Profissão, 39, 1-20. https://doi.org/10.1590/1982-3703003182761

Cómo citar: Mizael, T, M.; Gomes, A. R., \& Marola, P. P. (2019). Conocimientos de estudiantes de psicología sobre las normas de actuación con individuos LGBTs. Psicologia: Ciência e Profissão, 39, 1-20. https://doi.org/10.1590/1982-3703003182761 